\title{
Onikomikosis Kandida yang Diterapi dengan Itrakonazol Dosis Denyut Laporan Kasus
}

\author{
${ }^{1}$ Enricco H. Mamuaja, ${ }^{1}$ Ratna I. Susanti, ${ }^{2}$ Pieter L. Suling, ${ }^{2}$ Grace M. Kapantow
}

\author{
${ }^{1}$ Program Studi Ilmu Kesehatan Kulit dan Kelamin Fakultas Kedokteran Universitas Sam \\ Ratulangi Manado \\ ${ }^{2}$ Bagian/SMF Ilmu Kesehatan Kulit dan Kelamin Fakultas Kedokteran Universitas Sam \\ Ratulangi/RSUP Prof. Dr. R.D. Kandou Manado \\ Email: enricco.mamuaja@yahoo.com
}

\begin{abstract}
Candidiasis onychomycosis is a nail disorder caused by candida spp. as the most common cause in Indonesia. The first line therapy for this case is pulse dosing of itraconazole ( $2 \times 200 \mathrm{mg} /$ day for 7 days with 3-week interval); 2 pulse doses for finger nails and 3-4 pulse doses for toe nails. We reported a male of 60 years old with nail destruction and thickening of the thumb and ring finger of the right hand since six months ago. In the beginning, the nails appeared dull and then became yellowish, thickened, and brittled. Dermatology examination of the 1st and 4th finger of the right hand showed onycholysis, onychodistrophy, subungual hyperkeratosis, and yellowish discoloration. $\mathrm{KOH} 20 \%$ test found no long hypha with septa. Moreover, Gram staining showed no spora, budding cell, or pseudohypha. Repeated ten-day culture resulted in Candida parapsilosis. The treatment was succeded with two doses of itraconazole $2 \times 200 \mathrm{mg}$ for 7 days, with interval of 3 weeks. In this case, candidiasis onychomycosis was invasive in nails with onycholysis which looked like distal subungual onychomycosis. The growth of candida colony was fully spread in the Petri disk in 10 days, therefore, dermatophyte infection could not be excluded. Conclusion: Pulse therapy with twodose itraconazole succedeed in the treatment of candidiasis onychomycosis of the finger nails. Kata kunci: candidiasis onychomycosis, Candida parapsilosis, itraconazole pulse therapy
\end{abstract}

\begin{abstract}
Abstrak: Onikomikosis kandida adalah kelainan kuku akibat infeksi candida spp. yang merupakan penyebab terbanyak di Indonesia. Penatalaksanaan utama ialah itrakonazol dosis denyut (2x200 mg/hari selama 7 hari, istirahat 3 minggu) sebanyak 2 denyut untuk kuku tangan dan 3-4 denyut untuk kuku kaki. Kami melaporkan kasus seorang laki-laki 60 tahun dengan kerusakan dan penebalan kuku ibu jari dan jari manis tangan kanan sejak sekitar 6 bulan. Awalnya kuku berwarna putih suram kemudian berubah menjadi kekuningan, menebal dan rusak. Status dermatologikus memperlihatkan kuku jari I dan jari IV tangan kanan terdapat onikolisis, onikodistrofi, hiperkeratosis subungual, dan diskolorasi kekuningan. Pada pemeriksaan $\mathrm{KOH} 20 \%$ tidak ditemukan hifa panjang bersepta; pemeriksaan Gram tidak ditemukan spora, budding cell, dan pseudohifa. Hasil biakan berulang selama 10 hari ditemukan Candida parapsilosis. Terapi berhasil dengan pemberian itrakonazol 2x200 mg selama 7 hari, istirahat 3 minggu, sebanyak 2 denyut. Onikomikosis kandida pada kasus ini tergolong invasif pada kuku yang sudah onikolisis, menyerupai onikomikosis subungual distal. Pertumbuhan koloni kandida yang cepat memenuhi cawan menyebabkan lamanya kultur hanya 10 hari sehingga kemungkinan adanya infeksi dermatofita belum dapat disingkirkan. Simpulan: Terapi itrakonazol sebanyak 2 dosis denyut memperlihatkan keberhasilan pada onikomikosis candida di jari tangan.
\end{abstract}

Kata kunci: onikomikosis kandida, Candida parapsilosis, itrakonazol dosis denyut 
Onikomikosis adalah istilah umum untuk kelainan kuku akibat infeksi jamur, baik oleh dermatofita, nondermatofita, maupun ragi (yeast). Onikomikosis kandida adalah kelainan kuku akibat infeksi Candida spp. ${ }^{1}$ Dermatofita, yakni Trichopyton rubrum, Trichopyton mentagrophytes, dan Epidermophyton merupakan penyebab utama onikomikosis di Eropa dan Amerika Utara, sedangkan di Indonesia penyebab terbanyak ialah spesies Candida. Di Negara Barat dilaporkan prevalensi onikomikosis berkisar $2-18 \%$ dari populasi sedangkan di Indonesia, prevalensinya menunjukkan kisaran yang rendah, yakni 3,5-4,7\%, di antara kasus dermatomikosis. ${ }^{2}$ Berdasarkan penelitian dari Bramono $\mathrm{K}$ et $\mathrm{al}^{3}$ didapatkan insidens onikomikosis pada tahun 1997-1998 sebesar 3,5\% dan meningkat menjadi 4,7\% pada tahun 2003 . Pada penelitian yang sama didapatkan penyebab onikomikosis terbanyak ialah kandida $(50,1 \%)$, lebih banyak dibandingkan dermatofita $(26,2 \%){ }^{3}$

Faktor presdisposisi yang memudahkan terjadinya onikomikosis ialah kelembaban, oklusi, trauma berulang pada kuku, dan penurunan imnunitas (diabetes melitus dan infeksi HIV). Jenis kelamin laki-laki, usia lanjut, kanker, psoriasis, higiene yang buruk, dan hiperhidrosis juga merupakan faktor risiko. ${ }^{2.4}$

Terdapat tiga manifestasi klinis utama dari infeksi kandida pada kuku. Yang paling utama ialah onikomikosis subungual distal dan lateral onikolisis yang berhubungan dengan paronikia. Destruksi lengkap lempeng kuku dapat ditemukan pada beberapa pasien dengan kandidosis mukokutan kronik. Selain keadaan ini, erosi lempeng kuku distal dan lateral yang biasanya tidak berlanjut menjadi distrofi total juga dihubungkan dengan invasi kandida pada kuku. ${ }^{4,5}$

Pemeriksaan penunjang onikomikosis ialah pemeriksaan sediaan mikroskopik langsung diikuti pemeriksaan biakan untuk identifikasi spesies penyebab. Penentuan spesies bermanfaat untuk pemilihan jenis obat dan menilai prognosis. ${ }^{2}$

Penatalaksanaan onikomikosis berda- sarkan konsensus Eropa tahun 2005 menyatakan jika keterlibatan kuku lebih dari $50 \%$, dianjurkan diberikan terapi oral sebagai monoterapi atau kombinasi dengan topikal. Salah satu obat antijamur oral yang digunakan sebagai terapi onikomikosis ialah itrakonazol dengan dosis denyut 400 $\mathrm{mg} /$ hari selama seminggu setiap bulan dalam 2-3 bulan. ${ }^{2}$

Dilaporkan satu kasus onikomikosis kandida pada kuku jari tangan yang diterapi dengan terapi denyut itrakonazol.

\section{LAPORAN KASUS}

Seorang laki-laki berusia 60 tahun, suku Minahasa, tinggal di Desa Dimembe, datang ke Poliklinik Kulit dan Kelamin RSUP Prof. Dr. R. D. Kandou Manado pada tanggal 6 Mei 2016, dengan keluhan kerusakan dan penebalan di kuku jari manis dan ibu jari tangan kanan sejak sekitar 6 bulan lalu. Awalnya warna kuku terlihat agak suram kemudian menjadi kekuningan, menebal dan mulai mengalami kerusakan. Keluhan tidak disertai rasa gatal dan nyeri. Riwayat pasien pernah mengobati keluhan ini dengan salep Daktarin sekitar satu minggu tetapi tidak tampak perubahan. Pasien tidak memiliki riwayat penyakit diabetes melitus dan penyakit hati. Pasien merupakan pensiunan pegawai negeri sipil dan setiap hari beraktivitas di kebun milik keluarga.

Pada pemeriksaan fisik didapatkan status generalis pasien ini baik. Pada status dermatologik didapatkan regio digiti I dan IV manus dekstra memperlihatkan onikolisis, onikodistrofi, subungual hiperkeratosis, dan diskolorasi kekuningan. Hasil pemeriksaan Gram tidak didapatkan spora, budding cell, maupun pseudohifa. Pada pemeriksaan $\mathrm{KOH} 20 \%$ juga tidak didapatkan hifa panjang bersepta.

Diagnosis banding untuk kasus ini ialah onikomikosis kandida dan tinea unguium. Rencana terapi yang akan diberikan ialah terapi denyut itrakonazol (2x200 mg selama $1 \mathrm{minggu}$, istirahat 3 minggu) sebanyak 2 dosis denyut setelah ada hasil kultur kerokan kuku dan hasil pemeriksaan SGOT dan SGPT. 
Hari pertama kunjungan

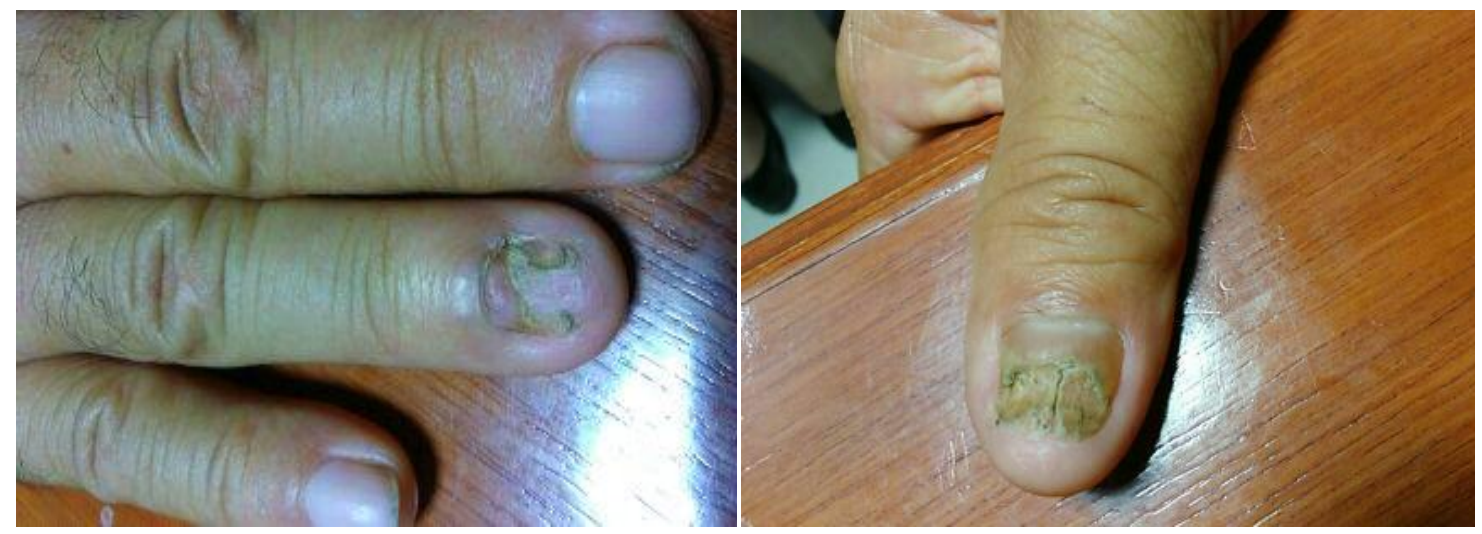

Kultur kerokan kuku pasien

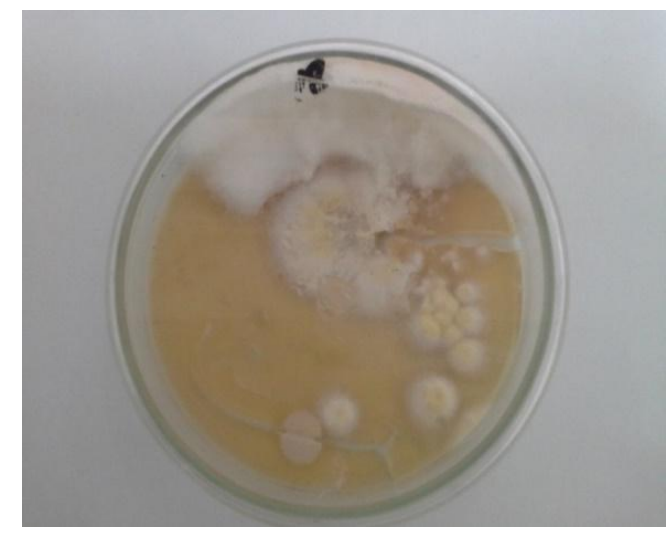

Hari terakhir kunjungan
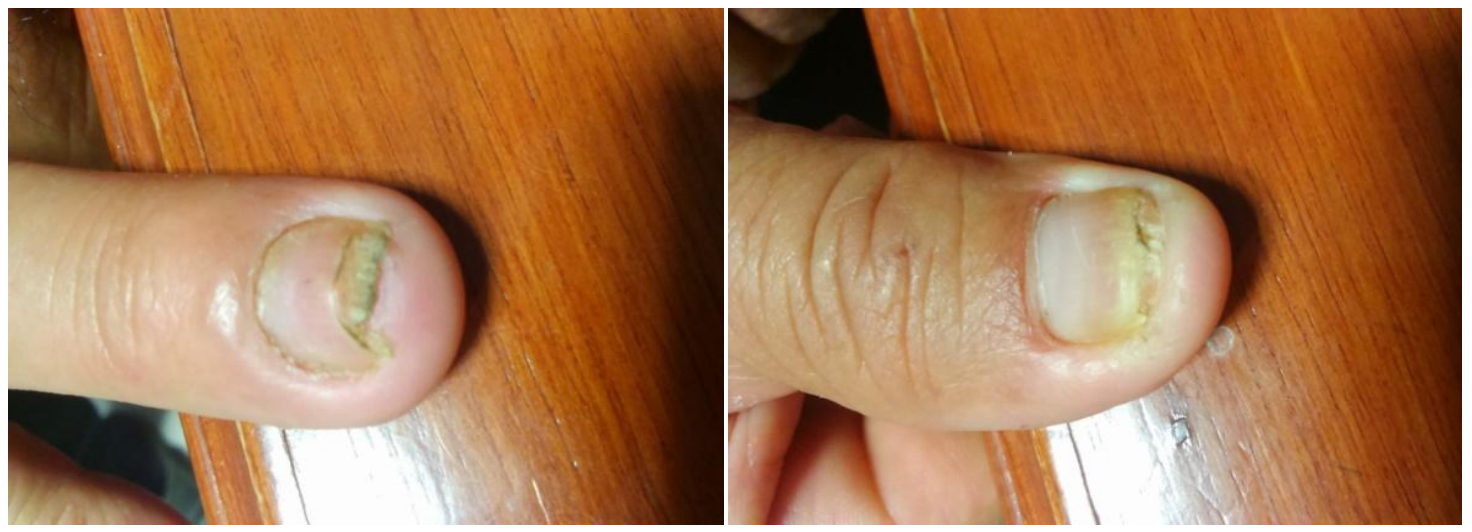

Pemeriksaan mikroskopik dengan pengecatan Gram tidak didapatkan spora, budding cell, maupun pseudohifa

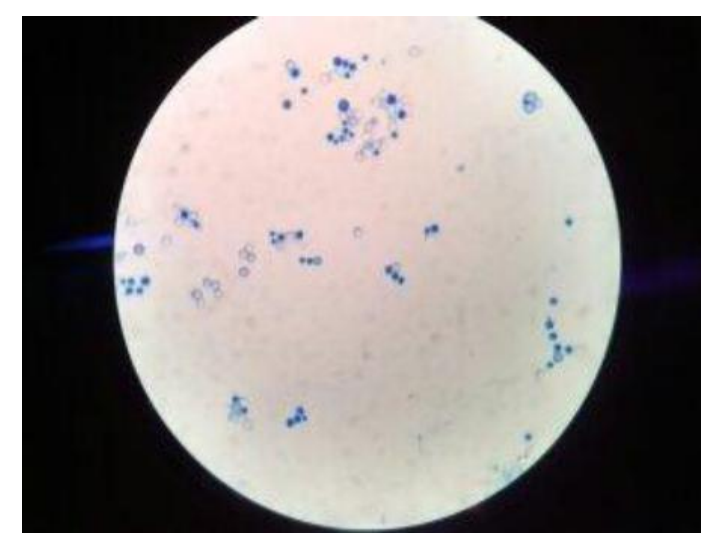

Gambar 1. Digiti I dan IV tangan kanan pasien sebelum dan setelah terapi dua kali dosis denyut itrakonazol

\section{BAHASAN}

Diagnosis onikomikosis kandida pada kasus ini ditegakkan berdasarkan anamnesis, pemeriksaan fisik, pemeriksaan laboratorium mikroskopik langsung, dan kultur. 
yang sedang memasuki usia lanjut (60 tahun).

Faktor predisposisi yang memudahkan terjadinya onikomikosis yaitu kelembaban yang tinggi, oklusi, trauma berulang pada kuku, dan penurunan imunitas. Gaya hidup tertentu, misalnya penggunaan kaos kaki dan sepatu terus menerus, olahraga berlebihan, serta penggunaan tempat mandi umum memudahkan terjadinya onikomikosis. $^{2}$ Pasien ini ialah seorang pensiunan pegawai negeri sipil yang setiap hari beraktivitas di kebun milik sendiri. Hal ini berhubungan dengan kelembaban yang cukup tinggi karena aktivitas sehari-hari di kebun, dan trauma berulang pada kuku yang merupakan faktor predisposisi terjadinya onikomikosis.

Perubahan warna kuku menjadi putih suram atau keperakan merupakan tanda awal onikomikosis, yang akhirnya menjadi kekuningan dan kecoklatan. ${ }^{5} \mathrm{Hal}$ ini sesuai dengan anamnesis berupa kuku jari manis dan jempol tangan kanan rusak dan menebal disertai warna kekuningan yang awalnya terlihat agak suram lalu kemudian terlihat menjadi kekuningan, menebal, dan mulai mengalami kerusakan.

Manifestasi klinis onikomikosis kandida ialah antara lain: 1) dimulai sebagai paronikia yang kemudian menginvasi matriks sehingga memberikan gambaran klinis depresi transversal kuku, kuku menjadi cekung, kasar, dan akhirnya distrofik; 2) Pada kandidosis mukokutan kronik, kandida langsung menginvasi lempeng kuku sehingga baru pada stadium lanjut tampak sebagai pembengkakan lipat kuku proksimal dan lateral yang membentuk gambaran pseudoclubbing atau chicken drumstick; 3) Invasi pada kuku yang sudah onikolisis, terutama terjadi pada kuku tangan, tampak sebagai hiperkeratosis subungual dengan massa abu-abu kekuningan di bawahnya, mirip onikomikosis subungual distal. ${ }^{5,7}$ Pada pemeriksaan fisik (status dermatologik) didapatkan regio digiti I dan IV manus dekstra memperlihatkan onikolisis, onikodistrofi, subungual hiperkeratosis, dan diskolorasi kekuningan; yang sesuai dengan salah satu manifestasi klinis onikomikosis kandida.

Beberapa jenis jamur tumbuh lambat ketika dikultur sehingga dibutuhkan waktu hingga 2 minggu sedangkan jamur jenis kandida dapat membentuk koloni dalam 13 hari. ${ }^{4}$ Kasus ini didiagnosis banding dengan tinea unguium, yang paling sering disebabkan oleh Trichophyton rubrum. Hasil pemeriksaan mikroskopik langsung dengan pengecatan Gram tidak ditemukan spora dan budding cell; pemeriksaan $\mathrm{KOH}$ $20 \%$ juga tidak mendapatkan hifa panjang bersepta. Pemeriksaan kultur kerokan kuku mendapatkan hasil biakan spesies Candida parapsilosis. Dilakukan kultur ulang dengan waktu kultur mencapai dua minggu untuk melihat apakah ada spesies jamur lain yang tumbuh. Setelah satu minggu lebih (10 hari), hasil biakan kembali menunjukkan spesies yang sama yaitu Candida parapsilosis, sehingga diagnosis onikomikosis kandida dapat ditegakkan tetapi adanya infeksi spesies lain seperti dermatofita belum dapat disingkirkan sepenuhnya karena belum memenuhi waktu kultur minimal untuk pertumbuhan spesies lain. Kesulitan yang ditemukan ialah pertumbuhan koloni kandida yang cepat memenuhi cawan dalam 10 hari sehingga meningkatkan risiko kontaminan dalam laboratorium. Selain itu, hasil biakan belum dapat menyingkirkan adanya infeksi spesies lain karena lamanya biakan yang belum mencapai batas minimal 2 minggu.

Individu dengan aktivitas berkebun dan trauma merupakan faktor risiko terkena infeksi Candida parapsilosis. Terjadi peningkatan laporan Candida parapsilosis sebagai spesies yang paling sering menyebabkan onikomikosis kandida. ${ }^{8} \mathrm{Hal}$ tersebut sesuai dengan hasil kultur kerokan kuku pada pasien yang ditemukan spesies Candida parapsilosis dan sesuai juga dengan aktivitas pasien yang suka berkebun.

Onikomikosis kandida efektif diterapi dengan itrakonazol oral dan merupakan terapi lini pertama. ${ }^{7,9-12}$ Itrakonazol merupakan antijamur derivat triasol, bersifat lipofilik dan keratofilik dengan 
mekanisme kerja menghambat sintesis ergosterol melalui penghambatan enzim cytochrome P450 14-alpha-demethylase sehingga memengaruhi integritas membran sel jamur. ${ }^{7,8}$ Terapi denyut itrakonazol bekerja aktif pada onikomikosis dengan jangka waktu yang dibutuhkan untuk terapi infeksi kuku jari kaki ialah 3-4 bulan. Terapi denyut itrakonazol didasarkan atas rasionalitas bahwa obat tersebut memiliki kadar terapi yang dapat mencapai kuku dalam 7 hari dan menetap selama 6 sampai 9 bulan. Kadar itrakonazol pada kuku masih dapat dideteksi sampai 12 bulan sesudah penghentian terapi denyut. ${ }^{2,7}$ Dosis itrakonazol yang digunakan ialah dosis denyut 2 x $200 \mathrm{mg} /$ hari selama 7 hari dengan istirahat 3 pekan sebanyak dua denyut untuk kuku tangan dan 3-4 denyut untuk kuku kaki. ${ }^{11}$ Pada kasus ini diberikan terapi denyut itrakonazol dengan dosis $2 \mathrm{x}$ $200 \mathrm{mg}$ sehari selama 1 minggu dalam sebulan dan diulang dengan dosis dan lama terapi yang sama pada bulan kedua. Setelah dua kali dosis denyut, terlihat perbaikan yang bermakna. Setelah dilakukan kultur ulang, tidak didapatkan pertumbuhan jamur sehingga dapat dikatakan pengobatan ini berhasil. Edukasi berupa penghentian kegiatan berkebun dapat membantu penyembuhan dan mencegah infeksi ulang.

Prognosis onikomikosis bergantung pada luas, bentuk klinis, dan faktor-faktor yang dapat memperburuk infeksi pada kuku. Prognosis kasus ini ialah quo ad vitam ad bonam, quo ad sanationam dubia ad bonam, dan quo ad functionam ad bonam.

\section{SIMPULAN}

Telah dilaporkan satu kasus onikomikosis kandida pada seorang lakilaki berusia 60 tahun yang berhasil dengan terapi denyut itrakonazol Diagnosis ditegakkan berdasarkan anamnesis, pemeriksaan fisik, dan hasil biakan spesies Candida parapsilosis walaupun belum dapat menyingkirkan adanya infeksi spesies lain karena lamanya biakan yang belum mencapai batas minimal 2 minggu.

Terapi denyut itrakonazol 2 x $200 \mathrm{mg}$ sehari selama 1 minggu tiap bulan dalam 2 bulan berhasil pada kasus ini.

\section{DAFTAR PUSTAKA}

1. Schieke SM, Garg A. Superficial fungal infection. In: Wolff K, Goldsmith LA, Katz SI, Gilchrest BA, Paller AS, Leffell DJ, editors. Fitzpatrick's Dermatology in General Medicine (8th ed). New York: Mc Graw Hill Inc, 2012; p. 2292-7.

2. Bramono K. Onikomikosis. In: Bramono K, Suyoso S, Indriatmi W, Ramali LM, Widaty S, Ervianti E, editors. Dermatomikosis Superfisialis (2nd ed). Jakarta: Badan penerbit Fakultas Kedokteran Universitas Indonesia, 2013; p. 86-99.

3. Bramono K, Budimulja U. Epidemiology of onychomycosis in Indonesia: data obtained from three individual studies. Jpn J Med Mycol. 2005;46:171-6.

4. Richardson MD, Warnock DW, editors. Fungal Infection Diagnosis and Management (4th ed). Chicester: John Wiley \& Sons, 2012; p. 21-23,128,135.

5. Hay RI, Moore MK. Mycology. In: Burn T, Breahnatch S, Cox N, Griffiths C, editors. Rook's Textbook of Dermatology (8th ed). Oxford: Blackwell Publishing, 2010; p. 36.56-64.

6. James WD, Berger TG, Elston DM. Andrew's Diseases of the Skin Clinical Dermatology (10th ed). Philadelpia: WB Saunders, 2011; p. 303-8.

7. Ameen M, Lear JT, Madan V, Mustapa MF, Richardson M. British Association of Dermatologists' guidelines for the management of onychomycosis 2014. British Association of Dermatologists. 2014;171:937-58.

8. Rieder E, Hu S, Meehan S, Adigun C. Candida parapsilosis of the nail-bed without onychomycosis. Dermatology Online Journal. 2015. Available from: URL:

http://escholarship.org/uc/item/17v3f8mk

9. Kundu RV, Garg A. Yeast infection: candidiasis, tinea (pityriasis) versicolor, and Malassezia (pityrosporum) folliculitis. In: Wolff $\mathrm{K}$, Goldsmith LA, Katz SI, Gilchrest BA, Paller AS, Leffell DJ, editors. Fitzpatrick's Dermatology in General Medicine (8th ed). New York: Mc Graw Hill Inc, 2012; p 2298-2307.

10. Hsu SP. Treatment principles and formulary. 
In: Arndt KA, Hsu JTS, editors. Manual of Dermatologic Therapeutics (7th ed). Philadelphia: Lippincott William and Wilkins, 2007; p. 273-9.

11. Gupta A, Paquet M. Mangement of onychomycosis in Canada in 2014. J Cutan Med Surg. 2015;19(3):260-73.
12. Suriadireja A, Toruan TL, Widaty S, Listyawan MY, SiswatiAS, Danarti R, et al. Dermatofitosis. In: Panduan layanan klinis dokter spesialis dermatologi dan venereologi. Jakarta: Perdoski, 2014; p. 35. 